\title{
The Differences Between Virtual and Video Counseling Towards Knowledge and Satisfaction of Mothers: A Comparative Study
}

\author{
Nur Chabibah $^{1}$, Warsiyah ${ }^{2}$ Fitriyani $^{3}$, Nina Zuhana ${ }^{4}$ \\ \{nchabibah@ymail.com ${ }^{1}$ \} \\ Department of Midwifery, Faculty of Health Science, Universitas Muhammadiyah Pekajangan \\ Pekalongan, 51173, Indonesia ${ }^{1,2,3,4}$
}

\begin{abstract}
The COVID-19 pandemic poses an authentic challenge health system in the world. Current demands for health services make health workers have to modify health services, especially in providing education in the event of a pandemic. The appropriateness of using the media will determine the increase in knowledge and client satisfaction. Objective: The Purpose of study was comparing the effectiveness of using virtual meeting and the use videos counseling in social media groups. Method: This study used a quasiexperimental design with a pre-test and post-test control group design approach. The population in this study was toddlers' mothers. Collecting data using e-form. This study finding increased knowledge of groups that were provided with counseling used virtual meeting method and groups that used counseling videos on group social media. Result: There were differences in service satisfaction by using virtual media meeting and counseling videos in social media groups, especially in the media used (p-value: 0.000). There was significantly increased target knowledge that received counseling with virtual meetings (p-value: $0.005, \mathrm{CI}$ : $-29.602-(-6.097))$ and video counseling in group social media (p-value: 0.000, CI: -10.081- (-9.017)). Conclusion: Extension based on virtual meeting is considered as a more effective media compared to the use of video extension in social media groups.
\end{abstract}

Keywords: Online counseling; virtual meetings; video counseling; toddler class

\section{Introduction}

An emerging global pandemic and wreak havoc on vulnerable world's population. Currently the acute respiratory outbreak is related to the coronavirus. This disease, called coronavirus 19 (COVID-19), is the third documenting animal-to-human coronavirus spills caused major epidemics in the last 2 decades [1]. Corona Virus Disease 2019 is a type of disease caused by infection with the Severe Acute Respiratory Syndrome Coronavirus 2 (SARS-COV2) [2].

The world order is currently being faced with various changes as a result of the corona virus outbreak. The spread of the corona virus has had a significant impact in various fields [3]. Following up on Government policies and to maintain the continuity of the world of education can continue to run well and support the Government in supporting physical distancing in the midst of the Covid-19 epidemic according to the president's instructions to stay at home, study at home, work at home, worship at home, Minister Education and Culture issued Circular 
Number 3 of 2020 on the Education Unit and Number 36962/ MPK.A / HK / 2020 concerning the Implementation of Education in the Coronavirus Disease (Covid-19). Emergency Period so learning activities are carried out online in in order to prevent the spread of coronavirus disease (Covid-19). Various efforts are being made by the government at this time to break the chain the spread of the virus is lockdown, social distancing, regional carat tern, but cannot be implemented optimally [4].

The Covid-19 era has forced the bureaucracy to optimize the use of technology, information and communication in all matters in the government sector. Due to limited space due to following health protocols, the public is still given the right as citizens to be served through electronic services. The transformation of the manual service model marked by faceto-face services to electronics continues to experience a significant increase during the Covid19 period. The functions of various technology applications are optimized to provide services to the community [5]. One form of technology application communication and information is the application of e-Health includes all functions that affect health sector. E-Health does not only cover on tools whose application is internet based, but all network information health, electronic health records, services telemedicine, a personal communication system wearable and portable, health portals and many other technologies and information which is based on helpful tools prevention, diagnosis, treatment, death health, and lifestyle management [6].

Various attempts were made by innovators to get it introduce an innovation to others. To can be accepted and applied by many people, then innovators must be able to identify a variety needs those others need. An innovation must be able to show various advantages and the benefits that exist in innovation. It should be an innovation has more advantages and benefits much in comparison to circumstances and conditions previous. The application of an innovation is expected improve the conditions and needs of others to be better than the previous condition. In addition, an innovation can be adopted by society absolutely must be able to be spread by communicate to the wider community with various ways [7]. In choosing the right digital counseling channel for patients, the counselor must provide an effective channel and not reduce the benefits of the counseling carried out. In this study, researchers compared two types of digital extension methods, namely by using virtual meeting channels and broadcasting information videos that were followed by discussions in social media groups. This study evaluation by looking at the increase in knowledge and satisfaction of patients who attend the counseling.

\section{Method}

This study used a comparative quantitative design with a quasi-experimental design (preexperimental design) in two groups who were given different interventions. The populations in this study were mothers who had children aged under five who attended the toddler class in Ambokembang Village, Kedungwuni District, Pekalongan Regency. The sample was divided into two groups, namely the group that was given education about toddler nutrition virtually (group 1) and the group that was given education video on nutrition for toddlers who shared through social media groups followed by discussions in that group (group 2). Evaluation of the influence of the intervention was carried out (follow-up) by looking at differences in client knowledge and satisfaction in following online counseling that had been followed. The sampling technique used in this research is systematic random sampling with the criteria of mothers under five who are registered in the toddler class in the village activities and participate 
in activities full time. The sample size in this study was 36 . However, 4 respondents in the intervention group were excluded because they did not participate full time. So that the total sample size is 32 respondents, 16 for the intervention group and 16 for the control group.

Collecting data used electronic questionnaires, in the form of a questionnaire about nutrition knowledge of toddlers and counseling of satisfaction service extension. These two questionnaires were used to assess the effect of the two treatments in the form of online counseling with different systems applied to clients. To measure the quality of services provided as a substitute for toddler class activities that have been routinely implemented. The questionnaire used is a questionnaire that has been tested for validity in previous studies for the knowledge questionnaire, which consists of 15 question items. The satisfaction questionnaire uses a Likert scale with 6 items of evaluation of implementation activities.

Data collection was carried out before the event began for the pre-test and after the question-and-answer discussion session related to the topic of extension material was carried out for the post test. E form data analysis was carried out using stata version 14. Statistical testing used t-test for numerical data and fisher exact test categorical data to test the effectiveness of differences in increased knowledge and differences in client satisfaction in two types of online counseling services applied to clients with degrees of significance $95 \%$.

\section{Results and Discussion}

\subsection{Results}

The results of the study of 32 respondents who attended the toddler class for 3 months in a row in two different groups are shown in the table below. Table 1 discusses the characteristics of mothers and toddlers they have.

Table 1. Characteristics of Toddlers and Mother Toddlers

\begin{tabular}{lccccc}
\hline \multirow{2}{*}{ Variable } & \multicolumn{2}{c}{ Intervention } & \multicolumn{2}{c}{ Control } & \multirow{2}{*}{ p-value } \\
\cline { 2 - 5 } & $\mathbf{n}$ & $\mathbf{\%}$ & $\mathbf{n}$ & $\mathbf{\%}$ & \\
\cline { 1 - 5 } Mother Background Education & & & & & \\
Lower secondary education & 2 & 12.5 & 4 & 25 & 0.205 \\
Upper secondary education & 14 & 87.5 & 12 & 75 & \\
\hline Mother's Work Status & & & & & \\
Workers & 8 & 50 & 10 & 62.5 & 0.255 \\
Housewife & 8 & 50 & 6 & 37.5 & \\
\hline
\end{tabular}

In Table 1, it can be seen that most of the mothers who have children with high school education are both senior high school and tertiary education. This is the strength of researchers in conducting virtual education which requires the ability of mothers to operate gadgets. While half of the mothers are housewives and some are working mothers. This shows the same opportunity to get health education during a pandemic. The condition of the working mother does not reflect the difficulties of the mother in taking virtual classes.

Table 2 shown the analysis of mothers' knowledge about toddler nutrition before and after health education was carried out through virtual meetings and through video counseling.

Table 2. Analysis of mothers' knowledge before and after attending virtual meetings and video counseling in social media groups 


\begin{tabular}{lccrr}
\hline Mother group & Before & After & p-value & CI 95\% \\
\cline { 2 - 3 } & Mean \pm SD & Mean \pm SD & & \\
\hline Virtual meeting & $64.904 \pm 9.303$ & $82.5 \pm 22.919$ & 0.005 & $-29.602-(-6.097)$ \\
Video counseling & $76.389 \pm 7.987$ & $85.938 \pm 8.985$ & 0.000 & $-10.081-(-9.017)$ \\
\hline
\end{tabular}

Table 2 shown a significant increase in knowledge both in the group that was given health education about toddler nutrition using the virtual meeting method ( $\mathrm{p}$-value: $0.005 ; \mathrm{CI}:-29.602$ $-(-6.097))$ and in the group that was given video counseling in the social media group (p-value: 0.000 ; CI : --10.081-(-9.017)).

Table 3 shown there is no difference in knowledge difference between before and after getting health education in the group with the virtual meeting method or video counseling ( $\mathrm{p}$ value: 0.158 ; CI: $-19.602-3.507)$.

Table 3. The difference in knowledge value difference between virtual meeting group and video counseling

\begin{tabular}{lcccc}
\hline \multirow{2}{*}{ Variable } & Virtual Meeting & Video Counseling & p-value & CI 95\% \\
\cline { 2 - 3 } & Mean \pm SD & Mean \pm SD & & \\
\hline $\begin{array}{l}\text { The difference in the } \\
\text { value of knowledge }\end{array}$ & $17.596 \pm 21.579$ & $9.549 \pm 0.998$ & 0.158 & $-19.602-3.507$ \\
\hline
\end{tabular}

Table 4 describes the level of satisfaction of mothers who participated in toddler class activities with two different methods, one group used virtual meetings and the next group used video counseling which was shared with social media groups.

Table 4. Analysis of differences in the level of satisfaction of mothers who attended virtual class meeting group and video counseling

\begin{tabular}{cccc}
\hline \multirow{2}{*}{ Satisfaction Level } & Virtual Meeting & Video Counseling & \multirow{2}{*}{ p-value } \\
\cline { 2 - 3 } & Percentage & percentage & \\
\hline Satisfaction & 59.38 & 50 & 0.236 \\
Very satisfied & 40.63 & 50 & \\
Satisfied & & & \\
\hline
\end{tabular}

Table 4 shown that the group who received counseling through the vitual meeting had higher satisfaction compared to the group who used video counseling even though the value was not statistically significant (p-value: 0.236 ).

\subsection{Discussion}

The results showed that there was an increase in knowledge in the two groups who took online counseling classes even though they used different methods. While the test results are significant differences in knowledge between the group that received counseling with virtual meetings (p-value: $0.005, \mathrm{CI}$ : $-29.602-(-6.097)$ ) and video counseling in group social media (p-value: 0.000 , CI: $-10.081-(-9.017)$ ). The use of technology can be a facility in increasing client knowledge with various media choices available in the era of the industrial revolution 4.0. Remote communication technologies are increasingly regarded as potential effective options to support health care interventions. Among them, telemedicine, virtual reality, augmented reality, and serious games could be in the forefront of these efforts [8]. The previous research state that online counseling continues to develop, in this case defined as the interaction process is not 
synchronous and asynchronous using chat media, e-mail, and video conferencing via the internet [9]. Synchronous process is the provision of counseling services through online activities concurrently which can be implemented via video call or text chat. Meanwhile, the asynchronous process is the process of providing services or counseling communication whose activities do not occur at the moment (do not occur in a direct) such as when sending messages [10].

However, by looking at the mean difference between the two groups, the group that received counseling with virtual meetings was higher, so it can be concluded that the use of counseling services with virtual meetings can increase the value of client knowledge higher than video counseling. This is possible because the use of virtual meetings, clients can meet face to face with the counselor and directly ask the things that are needed directly through verbal and listen to answers from the counselor directly. Another case with counseling through videos and discussions in social media groups, clients cannot respond directly to every response given by the counselor verbally, so it takes a long time to get a response.

In terms of satisfaction, there is no significant difference between the satisfaction of mothers who get counseling through virtual meetings and through video counseling ( $\mathrm{p}$-value: 0.236). But in the analysis of each aspect, namely the use of media in the two groups, it was found that the use of virtual meetings was more effective in delivering counseling ( $p$-value: 0.000). The review studies reported high levels of patient satisfaction with telegenetics, and patients were generally more receptive to telegenetics than the genetics practitioners [11]. Patients' satisfaction ratings with telemedicine visits remained unchanged despite the rapid uptake of telemedicine by virtually inexperienced providers (pre-COVID: $n$ 1/4 847, mean satisfaction $1 / 44.38 / 5$; post-COVID: $n$ 1/4 1693, mean satisfaction $1 / 44.38 / 5$ ) [12]. Other research results reveal that there are 4 problem factors in taking online classes during the COVID-19 pandemic, namely: 1) Facilities and technology, 2) Educators and teaching methods, 3) Personal 4) Family and other factors such as boredom and feelings which is not happy about the learning process that is being undertaken [13].

\section{Conclusion}

Both counseling methods increase mother's knowledge, but there is no significant difference in the value of mother's knowledge between virtual meeting method and video counseling. There is no difference in maternal satisfaction with the use of the two counseling methods, but the aspect of using virtual media is more satisfying to mothers. The use of virtual meetings in providing health education is recommended.

\section{Acknowledgement}

The author thanks the research institute and community service at the University of Muhammadiyah Pekajangan Pekalongan which has provided material and moral support in conducting research 


\section{References}

[1] T. Portnoy, J., Waller, M., \& Elliott, "Telemedicine in the Era of COVID-19," J. Allergy Clin. Immunol. Pract., vol. 8, no. 5, pp. 1489-1491., 2020.

[2] T. SINGHAL, "A review of coronavirus disease-2019 (COVID-19)," Indian J. Pediatr., pp. 1-6, 2020.

[3] W. A. F. Dewi, "Dampak Covid-19 terhadap implementasi pembelajaran daring di Sekolah Dasar Edukatif," J. Ilmu Pendidik., vol. 2, no. 1, pp. 55-61., 2020.

[4] N. F. Dai, "Stigma Masyarakat terhadap Pandemi Covid-19," Pros. Nas. Covid-19, pp. 66-73, 2020.

[5] H. Taufik, T., \& Warsono, "Birokrasi Baru Untuk New Normal: Tinjauan Model Perubahan Birokrasi Dalam Pelayanan Publik Di Era Covid-19.," Dialogue J. Ilmu Adm. Publik, vol. 2, no. 1, pp. 1-18., 2020.

[6] W. A. Setianto, "Inovasi e-Health Dinas Kesehatan Kota Surabaya,” J. Ilmu Komun., vol. 14, no. 3, pp. 151-164., 2016.

[7] B. Eprilianto, D. F., Sari, Y. E. K., \& Saputra, "Mewujudkan Integrasi Data Melalui Implementasi Inovasi Pelayanan Kesehatan Berbasis Teknologi Digital.," JPSI (Journal Public Sect. Innov., vol. 4, no. 1, pp. 30-37., 2019.

[8] S. Mantovani, E., Zucchella, C., Bottiroli, S., Federico, A., Giugno, R., Sandrini, G., ... \& Tamburin, "Telemedicine and virtual reality for cognitive rehabilitation: a roadmap for the COVID-19 pandemic," Front. Neurol., vol. 11, 2020.

[9] I. TANRIKULU, "Cyberbullying prevention and intervention programs in schools: A systematic review," Sch. Psychol. Int., vol. 31, no. 1, pp. 74-91., 2018.

[10] P. B. SCHOLL, Mark B.; HAYDEN, Seth CW; CLARKE, "Promoting optimal student engagement in online counseling courses," J. Humanist. Couns., vol. 56, no. 3, pp. 197-210., 2017.

[11] R. Hilgart, J. S., Hayward, J. A., Coles, B., \& Iredale, "Telegenetics: a systematic review of telemedicine in genetics services," Genet. Med., vol. 14, no. 9, pp. 765-776., 2012.

[12] R. Man, M. A., Toma, C., Motoc, N. S., Necrelescu, O. L., Bondor, C. I., Chis, A. F., ... \& Puiu, "Disease perception and coping with emotional distress during COVID-19 pandemic: A survey among medical staff," Int. J. Environ. Res. Public Health, vol. 17, no. 13, p. 4899., 2020.

[13] I. Von Humboldt, S., Mendoza-Ruvalcaba, N. M., Arias-Merino, E. D., Costa, A., Cabras, E., Low, G., \& Leal, "Smart technology and the meaning in life of older adults during the Covid-19 public health emergency period: a cross-cultural qualitative study," Int. Rev. Psychiatry, pp. 1-10., 2020. 